\title{
Transcription Factor SOX-21
}

National Cancer Institute

\section{Source}

National Cancer Institute. Transcription Factor SOX-21. NCI Thesaurus. Code C147884.

Transcription factor SOX-21 (276 aa, $29 \mathrm{kDa}$ ) is encoded by the human SOX21 gene.

This protein is involved in cellular differentiation and transcriptional regulation. 